\title{
Ovipleistophora gen. n., a new genus for Pleistophora mirandellae-like microsporidia
}

\author{
M. Pekkarinen ${ }^{1, *}$, J. Lom ${ }^{2}$, F. Nilsen ${ }^{3}$ \\ ${ }^{1}$ Division of Animal Physiology, Department of Biosciences, PO Box 17, 00014 University of Helsinki, Finland \\ ${ }^{2}$ Institute of Parasitology, Academy of Sciences of the Czech Republic, Branišovská 31, 37005 České Budějovice, Czech Republic \\ ${ }^{3}$ Institute of Marine Research, Department of Aquaculture, PO Box 1870, 5817 Bergen-Nordnes, Norway
}

\begin{abstract}
Based on ultrastructural study and molecular analysis, a new genus, Ovipleistophora, is established for Pleistophora mirandellae-like microsporidia from roach and ruff oocytes. Unlike Pleistophora, Ovipleistophora has a thick additional envelope around the meront. This envelope breaks open to release the cells into the host cell cytoplasm. The cells, becoming multinuclear sporogonic plasmodia, already have a surface coat that transforms into the sporont wall and eventually into the sporophorous vesicle wall. The surface coat and its transformation differ from those of Pleistophora, but bear some resemblance to those of Trachipleistophora. In Trachipleistophora the sporonts, however, do not form plasmodia, as they do in Ovipleistophora and Pleistophora. Small subunit ribosomal DNA analysis supports the establishment of the new genus and assignment of $P$. mirandellae from 2 different fish hosts to the same species. The same small subunit ribosomal DNA analysis lends support for transferring $P$. ovariae into the genus Ovipleistophora.
\end{abstract}

KEY WORDS: Pleistophora - Ovipleistophora $\cdot$ Microsporidian ultrastructure $\cdot$ Rutilus rutilus oocytes · Gymnocephalus cernuus oocytes · Molecular phylogeny

\section{INTRODUCTION}

Pleistophora mirandellae Vaney \& Conte, 1901, originally described from oocytes of a single specimen of common bleak Alburnus alburnus in France, has lately become known as a rather frequent parasite of this and other cyprinid fish (barbel Barbus barbus, chub Leuciscus cephalus, roach Rutilus rutilus) throughout Europe. Maurand et al. (1988) synonymised 3 species with P. mirandellae: P. elegans Auerbach, 1910 from the ovary of a hybrid Abramis brama $\times$ Rutilus rutilus from Germany; P. oolytica Weiser, 1949 from ovaries of Leuciscus cephalus and pike Esox lucius from the Czech Republic; and, finally, an assignment that still requires confirmation, $P$. longifilis Schuberg, 1910 from the testis of Barbus barbus from Germany. Otte (1964) reported the last species also from ovaries of

*E-mail: marketta.pekkarinen@helsinki.fi huchen, Hucho hucho, from Austria. These changes extended the host list to include fishes from 3 families. Findings of Pekkarinen (1996a) of a similar microsporidium in the common ruff Gymnocephalus cernuus further extend the host list of $P$. mirandellae.

Pleistophora mirandellae, judging from the identical appearance of spores from oocytes of different hosts, has been considered a single species of low host specificity. In general, the spores are dimorphic macrospores averaging $9.5 \mu \mathrm{m}$ in length and microspores $5.2 \mu \mathrm{m}$ in length; a third category that has sometimes been observed (see also Weiser 1949) is minute with an average length of $3 \mu \mathrm{m}$.

To determine the nature of the Pleistophora mirandellae-like microsporidia from ruffs we undertook the present study, which has raised doubt about whether the assignment of this and similar organisms to the genus Pleistophora is really justifiable. Previous studies of the ultrastructure of $P$. mirandellae were incomplete (Maurand et al. 1988, Pekkarinen 1995, 1996a,b); 
thus, the present study is aimed to improve the knowledge of the stages of the parasite.

\section{MATERIALS AND METHODS}

Sampling and microscopy. Individuals of Gymnocephalus cernuus (L.) were collected in Lake Juurusvesi, central Finland. Additionally, Rutilus rutilus (L.) were collected in the coastal brackish water south of Finland. Ovaries of the fishes were examined while fresh, or after preservation in Lillie's buffered formalin. From native preparations spores were separated and washed in distilled water. For light microscopy, samples were placed in Bouin's fixative and processed for routine paraffin embedding. Sections were stained with haematoxylin and eosin, and Gomori's and Crossmon's trichrome stains. For transmission electron microscopy, samples from ruff ovaries were prefixed in phosphate-buffered (0.1 M, pH 7.2) $2.5 \%$ glutaraldehyde and postfixed in $2 \% \mathrm{OsO}_{4}$. After washing and dehydration the samples were embedded in Epon. The ultrathin sections were treated with uranyl acetate and lead citrate. The preparation and examination were done partly in the University of Helsinki (EM unit, Department of Biotechnology, with a Jeol JEM 1200EX electron microscope) and partly in the Institute of Parasitology, Academy of Sciences of the Czech Republic (Jeol JEM 1010 electron microscope).

Nucleic acid preparation. Spores were stored in $70 \%$ ethanol until use. An aliquot of spores obtained from Gymnocephalus cernuus was transferred to double-distilled water and washed several times with repeated centrifugation in a Microfuge (Micromax) at $4000 \times g$ for $2 \mathrm{~min}$. The spores were then suspended in digestion buffer $(100 \mathrm{mM} \mathrm{NaCl}, 10 \mathrm{mM}$ Tris- $\mathrm{HCl}$, $25 \mathrm{mM}$ EDTA, $0.5 \%$ sodium dodecyl sulphate, $\mathrm{pH}$ 8.0) containing $0.5 \mathrm{mg} \mathrm{ml}^{-1}$ Proteinase $\mathrm{K}$ and incubated overnight at $37^{\circ} \mathrm{C}$. Nucleic acid was then extracted twice with an equal volume of chloroform/phenol, followed by an equal volume of chloroform, and then ethanol precipitated. The precipitated DNA was dissolved in $100 \mu \mathrm{l}$ double-distilled water.

Polymerase chain reaction (PCR). The PCR was carried out as described previously (Nilsen 2000). Briefly, a set of primers (V1f and 1492r) was used to amplify the majority of the small subunit ribosomal DNA (rDNA) gene. PCR was conducted in $100 \mu \mathrm{l}$ reactions using 20 pmol of each primer, $20 \mathrm{nmol}$ of each deoxyribonucleoside-5'-triphosphate, $10 \mu \mathrm{l}$ 10X Taq polymerase buffer (Advanced Biotechnologies), 2.5 units Taq polymerase and $1 \mu \mathrm{l}$ of the genomic DNA. The reactions were run on a Perkin Elmer thermocycler for 35 cycles at $94^{\circ} \mathrm{C}$ for $1 \mathrm{~min}, 50^{\circ} \mathrm{C}$ for $1 \mathrm{~min}$ and $72^{\circ} \mathrm{C}$ for $2 \mathrm{~min}$. After completion of the 35 cycles, a $10 \mathrm{~min}$ extension at $72^{\circ} \mathrm{C}$ was applied. PCR products were visualised by running $10 \mu \mathrm{l}$ aliquots on a $1 \%$ agarose gel and then purified on a $1 \%$ low melting agarose gel. The band of desired size (approximately $1350 \mathrm{bp}$ ) was then excised from the gel.

Cloning and sequencing. The purified PCR product was sequenced in both directions using BigDye on an ABI prism 3770 sequencer. An aliquot of the purified PCR product was cloned into a TOPO TA cloning vector (Invitrogen) as described by the manufacturer. Plasmid from 1 clone containing an insert of correct size was partially sequenced using vector primers as described above.

Phylogenetic analysis. An alignment consisting of 46 microsporidian 16S RNA sequences was made as described by Nilsen (2000). Phylogenetic analyses were performed using PAUP* 4.0 Version 4b4a (Swofford 2000). The data were analysed using parsimony, distance analysis and maximum likelihood. The parsimony analysis was performed using heuristic search with random addition of sequences and 100 subreplicates. For the distance analysis, the general time reversal model distance measurement was used together with minimum evolution (Swofford 2000). For the maximum likelihood the nucleotide frequencies were estimated from the data set. To adjust for rate heterogeneity, a 4 category gamma distribution was used where the shape parameter was estimated from the data set $(=0.379)$. The employed model contained 2 substitution types and the transition to transversion ratio was estimated $(=1.166)$. One thousand bootstrap replicates were run using both parsimony and distance as optimality criteria.

The following species, used in the phylogenetic analysis, were obtained from GenBank ${ }^{1}$ : Antonospora scoticae (AF024655), Amblyospora californica (U68473), Amblyospora sp. (U68474), Ameson michaelis (L15741), Bacillidium sp. (AF104087), Culicosporella lunata (AF027683), Edhazardia aedis (AF027684), Encephalitozoon cuniculi (L39107), E. hellem (L39108), Endoreticulatus schubergi (L39109), Enterocytozoon bieneusi (L07123), Glugea anomala (AF104084), G. atherinae (U15987), G. stephani (AF056015), Ichthyosporidium sp. (139110), Intrapredatorus barri (AY013359), Janacekia debaisieuxi (AJ252950), Kabatana takedai (AF356222), Loma acerinae (AF356224), Loma sp. (AF104081), Microgemma sp. (AJ252952), Microsporidium prosopium (AF151529), Nosema bombycis (D85504), Nucleospora salmonis (U78176), Heterosporis anguillarum (U47052), Heterosporis sp. (AF356225), Pleistophora mirandellae (AF104085), P. typicalis (AF104080),

\footnotetext{
${ }^{1}$ We do not wish to comment here on the practice of introducing new generic names without regularly describing them first (Visvesvaria)
} 
Pleistophora ovariae (AJ252955), Pleistophora sp. 2 (AF104083), Pleistophora sp. 3 (AF104082), Pleistophora sp. A (U10342), Pleistophora sp. PA (AJ252958), Parathelohania anophelis (AF027682), Septata intestinalis (L39113), Spraguea lophii LP (AF104086), Spraguea lophii LA (AF033197) Thelohania solenopsae (AF134205), Trachipleistophora hominis (AJ002605), Vairimorpha necatrix (Y00266), Vavraia culicis (AJ252961), V. oncoperae (X74112), Visvesvaria algerae (AF024656), V. acridophagus (AF024658) and Vittaforme corneae (L39112).

\section{RESULTS}

\section{Light microscopy of the life stages of the microsporidian from the roach and ruff}

In the populations of the oocytes from both hosts, young merogony stages were observed in the oocyte cytoplasm to have a homogeneous, structureless envelope, which in uninucleate stages was closely applied to the cell. In the series from both roach (Figs. 1, $2 \& 3$ ) and ruff oocytes (Figs. 4, 5 \& 6) growth was observed from uninucleate cells through 2-cell stages and eventually to stages with many cells within the envelope. The common envelope around the cell group eventually reached a thickness of about 4 to $6 \mu \mathrm{m}$ in roach and 2 to $3 \mu \mathrm{m}$ in ruff oocytes (Figs. $3 \& 6$ ). The uninucleate meronts with their envelopes measured about 6 to $10 \mu \mathrm{m}$ and multicellular forms in roach oocytes reached 30 to $40 \mu \mathrm{m}$ in diameter. The envelope containing dividing parasite cells, some of them again multinucleate, eventually ruptured (Fig. 7).

Merogony was followed by sporont formation, segmentation and eventual differentiation through sporoblasts into micro- and macrospores (Figs. 8 \& 9). The final stage was an almost complete replacement of oocyte cytoplasm by parasite stages and spores (Figs. 10 \& 11).

\section{Electron microscopy of the stages in ruffs}

The early merogonial stages were frequently near the oocyte nucleus. Even in these stages (Figs. 12, 13 $\& 14$ ) the plasmalemma was covered by a membranous wrinkled layer appearing as forked ledges up to $0.3 \mu \mathrm{m}$ high and filled with dense substance (Fig. 14). The meront cells displayed a variety of small vesicles, free ribosomes and stacks of endoplasmic reticulum (Fig. 14).

The thick envelope closely applied to the cells seen in the light micrographs adhered immediately to the wrinkled layer (Figs. 13 \& 14). It consisted of a mass of small (about 60 to $100 \mathrm{~nm}$ ), often anastomosing vesicles (Fig. 15) with a finely granular amorphous matter between them. This vesicular zone had no clear outer boundary, as it interlocks with the oocyte cytoplasm, which is differentiated by the presence of a mass of free ribosomes absent from the vesicular zone. In the space between the meronts (Fig. 16) there were sometimes elongate vesicles with a periodically striated axis, vaguely reminiscent of the bodies of vesicular stomatitis virus. In the space between the rather closely adhering meronts (Fig. 17) the finely granular matter contained electron-dense ramifications of the forked surface ledges of the cells.

When the stages were released from the thick merogonial envelope, which broke open (Fig. 18), the ledges started growing in what was already the wall of the sporont, i.e. the sporogonial plasmodium. When these plasmodia started to increase considerably in volume, the ledges filled with the dense substance formed a labyrinth of partitions and little spaces (Fig. 19). Later, the dense matter and some vesicles surrounding the plasmodia were flattened against the surface. The plasmodia that are destined to produce macrospores have a 'hairy' type of surface ornamentation (Fig. 20) while those destined to grow much more in volume and to produce microspores have a 'railfence' type of surface coat (Fig. 21). Finally, when the sporoblasts detached from the surface coat, the the dense matter and the flattened membranous cisternae at the wall of the sporophorous vesicle (SPV) appeared to be reversed (Fig. 22), as described by Pekkarinen (1996b) in roach oocytes.

\section{Small subunit rDNA analysis}

The amplified PCR product from Pleistophora mirandellae from Gymnocephalus cernuus was 1363 bp with a GC content of $50.4 \%$. The sequence has been submitted to GenBank with accession number AF356223. The length is very similar to that of $P$. mirandellae 16S rDNA amplified from Rutilus rutilus. In GenBank there are 2 deposited sequences of $P$. mirandellae from $R$. rutilus sequenced by others (accession number AJ252954, Cheney et al. [2000] and AF104085, Nilsen [2000]). Alignment of these three 16S rDNA sequences revealed only a few differences, most of them probably being errors due to amplification or sequencing artefacts. Hence, in the following phylogenetic analyses we use the sequence obtained from G. cernuus (present study) and 1 of the sequences from GenBank (accession number AF104085).

Using parsimony, distance analysis and maximum likelihood analysis we obtained phylogenetic trees with very similar overall topology (Fig. 23). The phylogenetic analysis consistently placed the 2 Pleistophora mirandellae sequences together with 


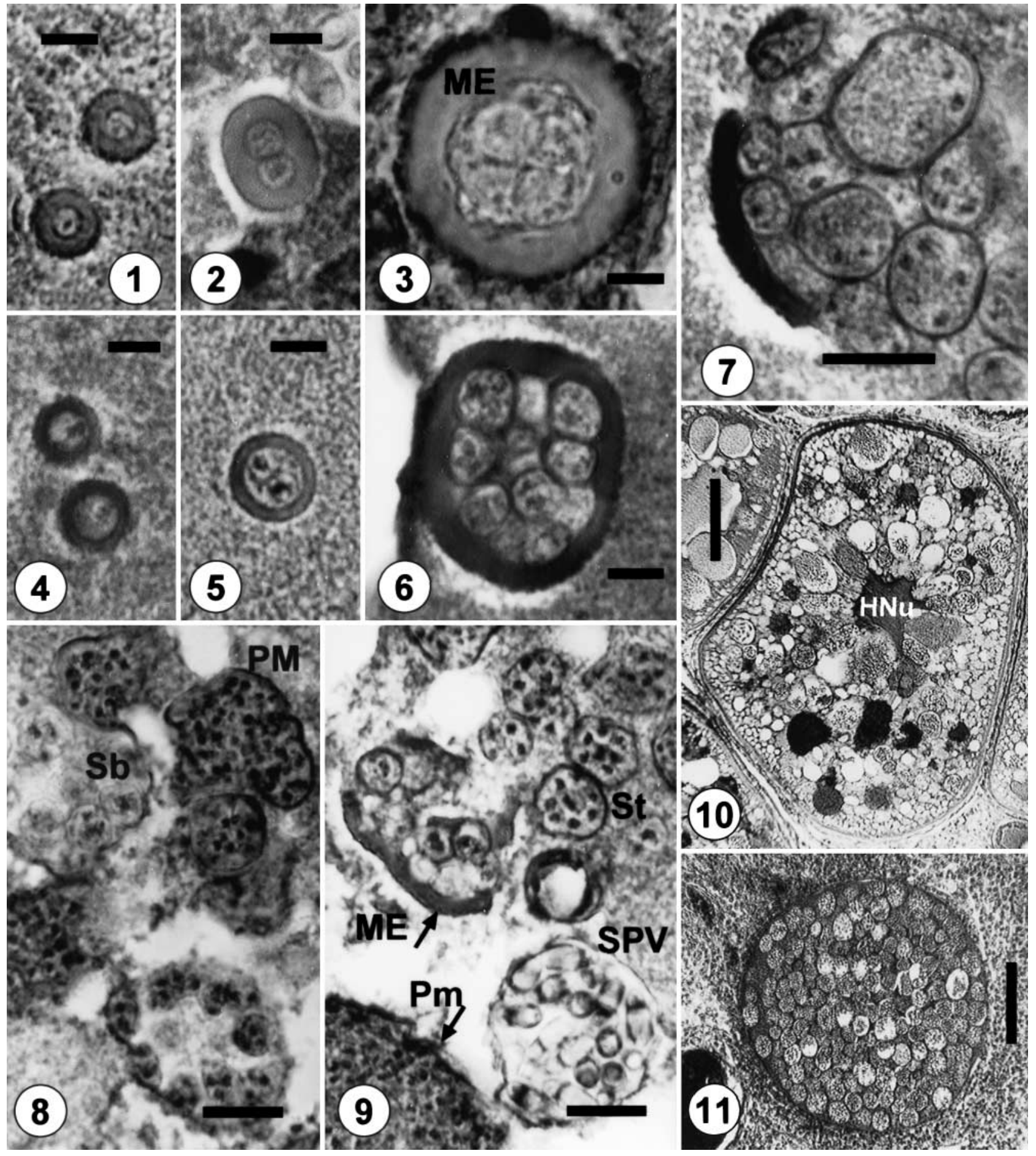

Figs. 1 to 11. Light microscopy of stages of Ovipleistophora. Fig. 1. Uninucleate meronts within their envelopes in roach oocyte. Fig. 2. Two-cell stage from roach oocyte. Fig. 3. Multicellular meront in roach oocyte. Figs. 4, 5 \& 6 . The same stages in ruff oocytes. Fig. 7. The meront envelope has broken and plasmodia released in the cytoplasm of ruff oocyte. Fig. 8. Division of sporonts and formation of sporoblasts in ruff oocyte. Fig. 9. Sporonts, macrospores and a larger plasmodium producing microspores in ruff oocyte (broken meront envelope also visible [arrow]). Fig. 10. Ruff oocyte almost full of parasite stages and sporophorous vesicles. Fig. 11. Roach oocyte crowded by sporophorous vesicles. HNu: nucleus of host oocyte; ME: meront envelope; Pm: plasmodium to produce microspores; PM: plasmodium to produce macrospores; Sb: sporoblasts; SPV: sporophorous vesicle; St: sporont. Scale bars $=5 \mu \mathrm{m}$ (Figs. 1 to 6), $10 \mu \mathrm{m}$ (Figs. 7 to 9) and $100 \mu \mathrm{m}$ (Figs. 10 \& 11). Staining: Gomori's trichrome (Figs. 1, 5 \& 10), haematoxylin and eosin (Figs. 2, 3 \& 11), Crossmon's trichrome (Figs. 4, 6 to 9) 




Figs. 12 to 16. Transmission electron microscopy (TEM) of Ovipleistophora meronts from ruff oocytes. Fig. 12. Young meront. Fig. 13. Middle-aged meront. Fig. 14. Meront cells enlarged from Fig. 13. Fig. 15. Meront envelope and host cell cytoplasm. Fig. 16. Bodies in the spaces between meronts. HCy: host cell cytoplasm; MC: meront cytoplasm; ME: meront envelope SL: surface ledges. Scale bars $=1 \mu \mathrm{m}$ (Fig. 12), $2 \mu \mathrm{m}$ (Figs. $13 \&, 14), 200 \mathrm{~nm}$ (Figs. $15 \& 16$ ) 


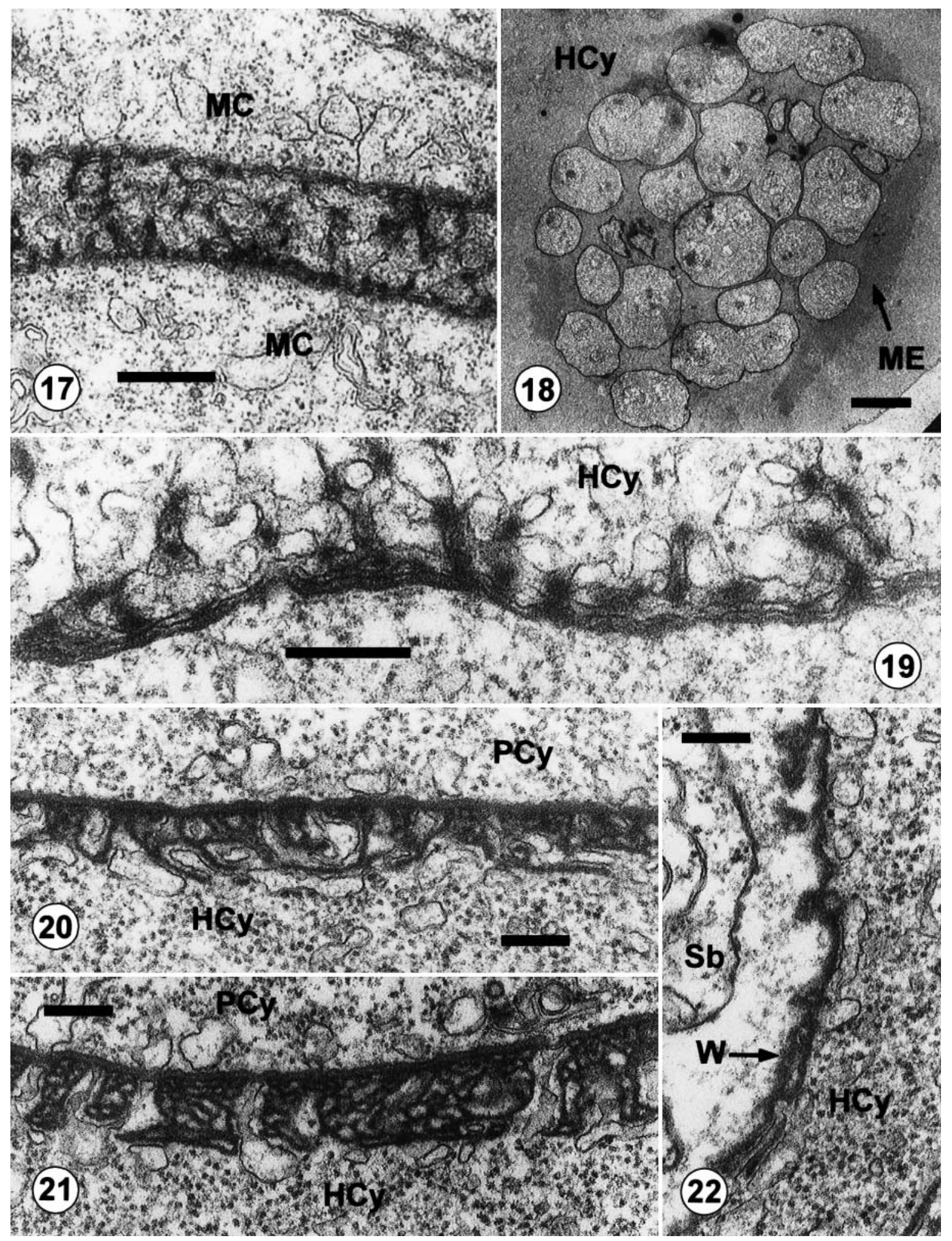

Figs. 17 to 22. TEM of Ovipleistophora from ruff oocytes. Fig. 17. Surface ledges between 2 adjacent meront cells. Fig. 18. Meront envelope broken and cells released into host cell cytoplasm. Fig. 19. Wall of young sporont. Fig. 20. 'Hairy' wall of sporogonial plasmodium producing macrospores. Fig. 21. Wall of a large, microspore-producing plasmodium (rail-fence type). Fig. 22. Wall of a vesicle containing sporoblasts. HCy: host cell cytoplasm; MC: meront cytoplasm; ME: meront envelope; Pcy: plasmodium cytoplasm; Sb: sporoblast; W: wall of SPV. Scale bars $=400 \mathrm{~nm}$ (Fig. 17), 5 m (Fig. 18), $200 \mathrm{~nm}$ (Figs. 19 to 22) 
$100 \%$ bootstrap support. These 2 sequences group together with $P$. ovariae, also supported by $100 \%$ in the bootstrap analysis. There are several differences between the $P$. ovariae and the $2 P$. mirandellae sequences. In particular there is an 8 bp insert (starting at position 1035 in the Gymnocephalus cernuus sequence) in the $P$. ovariae sequence and 2 small areas (starting at position 771 and 1155 in the G. cernuus sequence) with well-defined differences. Both $P$. mirandellae and $P$. ovariae infect the oocytes of fish, and the phylogenetic analysis clearly distinguishes them from the typical Pleistophora spp. infecting the

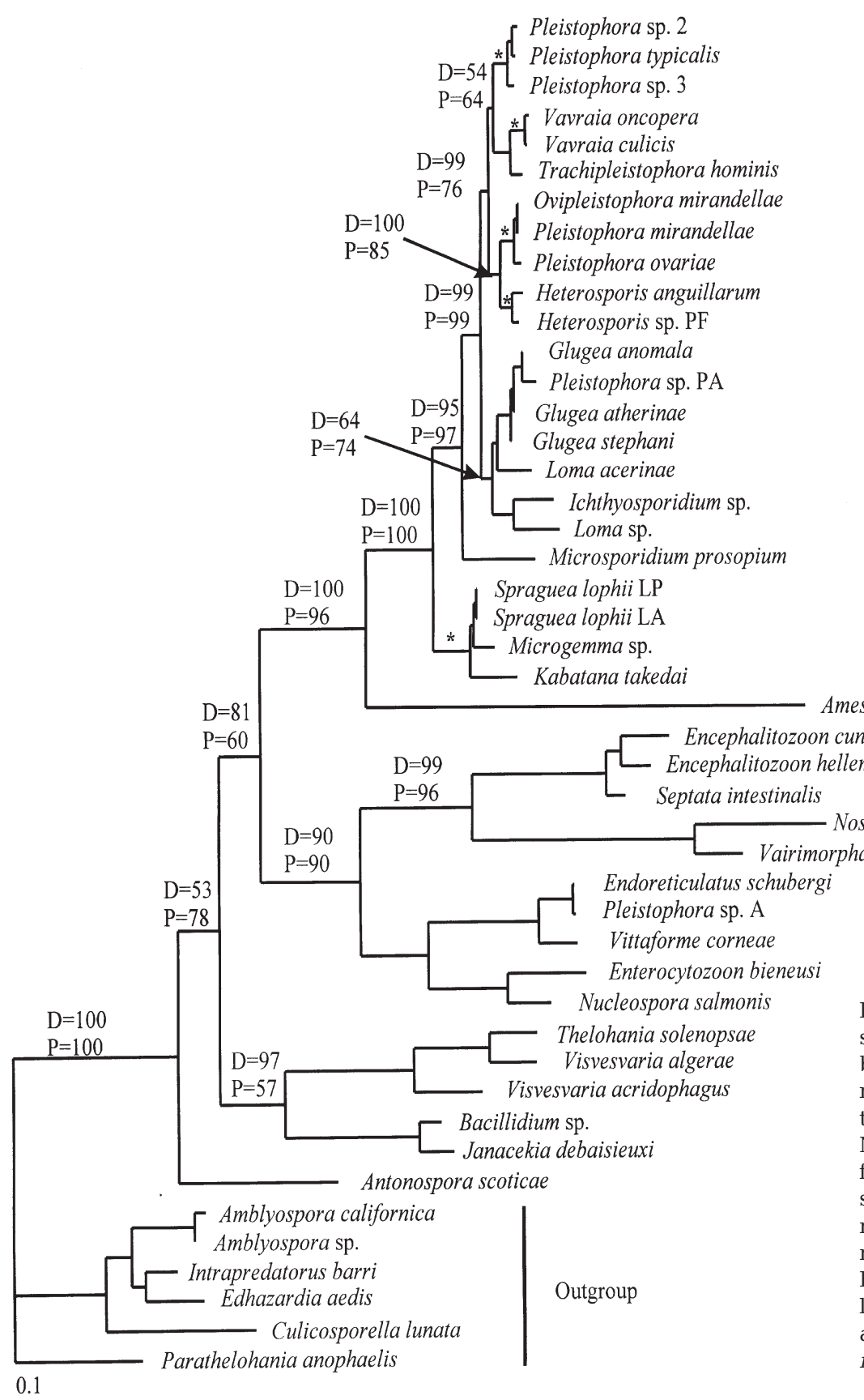

skeletal muscle of fish. In the present study the oocyte-infecting 'pleistophorans' clustered together with 2 Heterosporis species, forming a sister group to that consisting of 'true' Pleistophora spp. (i.e. P. typicalis and Pleistophora sp. 2 and sp. 3) and Vavraia/ Trachipleistophora (Fig. 23). The phylogenetic analyses strongly support placing the oocyte-infecting fish microsporidia in 1 genus and for assignment of $P$. mirandellae obtained from the 2 different host species to the same species.

\section{DISCUSSION}

\section{Morphology}

The meront surface coats and their transformation into the walls of sporonts and SPVs are important differences between the species Pleistophora typicalis (Canning \& Nicholas 1980) (and the very similar $P$. littoralis; Canning et al. 1979) and the species described above.

The clearest difference is the presence of a thick envelope around meronts - which appears amorphous in light micrographs - of the microsporidian species in roach and ruff oocytes. In electron microscopy the envelope is seen to consist of small membrane-bound
Fig. 23. Maximum likelihood tree with 46 microsporidia 16S rDNA sequences. The numbers on the branches are the bootstrap support obtained by parsimony (P) and distance (D) as optimum criteria. One thousand replicates were used with both methods. Nodes with an asterisk have $100 \%$ bootstrap support for both parsimony and distance analysis. Only a selection of bootstrap values is shown for ease of reading. Pleistophora sp. 2 and Pleistophora sp. 3 correspond to the same species as in Nilsen et al. (1998). Branch lengths are calculated using maximum likelihood analysis in PAUP* 4.0 Version 4b4a. Host name abbreviations: PA: Penaeus aztecus; PF: Perca flavescens; LA: Lophius americanus; LP: L. piscatorius 
vesicles and finely granular matter, which may be produced partly by the uninucleate meronts and partly by the host oocyte. This envelope is missing in P. typicalis and $P$. littoralis. The envelope, however, vanishes later and thus releases the contents (uni- and multinucleate stages) into the host cell cytoplasm.

In Pleistophora typicalis, described by Canning \& Nicholas (1980) and Canning \& Hazard (1982), plasmodial meronts are covered by a hyaline, electronlucent layer permeated by channels extending from the plasmalemma to a layer of vesicles at the surface. The wall divides along with the plasmodia. The hyaline channel-containing wall is missing in the species of this study.

The sporont wall in Pleistophora typicalis and P. littoralis originates by transformation from the electronlucent meront wall. In P. typicalis, a band of dense granules appears mid-way across the persisting amorphous coat of the sporont; later, within this band, the previously uniform substance of the coat transforms into an aggregate of spherical vesicles. In P. littoralis, the electron-dense material may be deposited close to the plasmalemma and later forms digitations at the surface of the SPV (Canning et al. 1979).

The primordium of the sporont wall of the roach and ruff parasites also exists as early as at the meront stage. Instead of electron-lucent material, it consists of ledges of electron-dense material subtended by membranes. The sporont wall looks like a labyrinth of partitions with dense substance. Vesicles between the dense matter ledges may be flattened against the plasma membrane due to increase of the volume of the sporogonial plasmodium. Later, when the sporoblasts detach from the labyrinth-like surface coat, the labyrinth transforms into a layer of amorphous dense substance covered by flat membranous cisternae (Pekkarinen 1996b).

As for the only other oocyte-infecting Pleistophora species, P. ovariae, it can be seen from the light micrographs published by Summerfelt \& Warner (1970) that early meronts are encased within a thick envelope similar to that of the species previously known as $P$. mirandellae. The envelope, however, seems to divide along with the cells. An ultrastructural study of $P$. ovariae would be of value. Sporonts of $P$. hyphessobryconis from muscle tissue of Paracheirodon inessi also have a homogeneous wall permeated by channels, although older sporonts are enveloped by a meshwork surrounding electron-dense particles. Walls of mature SPVs seem to be similar to those of the species of this study (Lom \& Corliss 1967).

While a possible relation to Heterosporis anguillarum is supported only to a limited extent by morphological features of the SPV wall, the labyrinth-like walls of Pleistophora mirandellae meronts find their counterpart in similar structures of Trachipleistophora hominis (Hollister et al. 1996). T. hominis, however, differs from Pleistophora and Ovipleistophora by not having plasmodial stages of sporonts. The identities of many species of the Pleistophora group may still be obscure.

The Pleistophora mirandellae-like species (Ovipleistophora mirandellae) from roaches and ruffs from Finland reveal some slight morphological differences between each other (Pekkarinen 1996a, Pekkarinen \& Lom 1999); however, molecular analysis suggests that they constitute 1 species. P. mirandellae was originally described by Vaney \& Conte (1901) from Alburnus alburnus from France. Therefore, the ultrastructure of the microsporidia from this host warrants comparative examination. In the meantime, the parasites of ruff and roach are considered to be $P$. mirandellae. No microsporidia have been found from bleaks in Finland and thus ultrastructure of a vicarious $P$. mirandellae from an original host could not be compared in this study.

\section{Molecular phylogeny}

In a study of microsporidian phylogeny by Nilsen (2000), it was suggested that Pleistophora mirandellae is not a member of the genus Pleistophora and that a new genus should be established for this species. Cheney et al. (2000) later confirmed this opinion. The typical Pleistophora spp. infect the skeletal muscle of fish, but several other species from non-fish hosts and species infecting other tissues have been assigned to this genus (Canning \& Hazard 1982, Nilsen et al. 1998, Nilsen 2000). The overall topology of the phylogenetic tree obtained in the present study is similar to that of Nilsen (2000), even if several more sequences have been included in the present study. The present phylogenetic analysis shows with high confidence that the 2 $P$. mirandellae isolates obtained from 2 different host species (i.e. Gymnocephalus cernuus and Rutilus rutilus) are closely related and certainly belong to the same genus. Until more evidence of transmission of $P$. mirandellae between different host species or molecular data are available, it is suggested that these 2 isolates belong to the same species. Our phylogenetic analysis also shows that $P$. ovariae is closely related to $P$. mirandellae and should be included in the same genus. This confirms the results by Cheney et al. (2000), who found that $P$. mirandellae and $P$. ovariae are separate but closely related.

There are a few differences between the present phylogenetic analysis and the phylogenetic tree presented by Cheney et al. (2000). In the present study 46 microsporidian sequences have been included in the phylogenetic analysis, compared with Cheney et al. 
(2000), who used 23 different sequences. For the fishinfecting microsporidia the difference is mainly due to the fact that we have obtained sequence data from several more species. In the present study we obtained low bootstrap support for 2 nodes. The node leading to Pleistophora typicalis/Pleistophora sp. 2/Pleistophora sp. 3 and Vavraia culicis/V. oncoperae/Trachipleistophora hominis gave only 54 and $64 \%$ support in the bootstrap analysis using distance and parsimony, respectively. Furthermore, the node separating Loma sp./Ichthyosporidium sp. from the clade containing $G$. anomala shows a bootstrap support of $64 \%$ (distance) and $74 \%$ (parsimony). In the tree presented by Cheney et al. (2000) they were not able to resolve clearly the clade containing Glugea, Ichthyosporidium and Loma or the position of $P$. mirandellae and $P$. ovariae. One reason for this may be that they used only parsimony in their bootstrap analysis and that they had no Heterosporis-like sequences in their analysis.

In conclusion, both morphological and molecular data support the establishment of a new genus for oocyte-infecting fish microsporidia. At present this genus contains 2 species, Ovipleistophora mirandellae (Vaney \& Conte, 1901) comb. nov. and O. ovariae (Summerfelt, 1964) comb. nov. Based on 16S rDNA phylogeny this genus should be situated within the family Pleistophoridae.

\section{Morphological definition of the genus Ovipleistophora}

- The type species is Ovipleistophora mirandellae (Vaney \& Conte, 1901) comb. nov.

- Nuclei are isolated throughout development. Uninucleate meronts are covered by an elaborate surface coat formed as membrane-bound contorted ledges with dense cores. This surface coat divides along with the cells. In addition, meronts are enveloped by a common, closely adhering thick envelope, consisting of a mass of diverse vesicles in a finely granular substance. The envelope does not divide together with the meronts.

- Eventually, the thick common envelope enclosing the meront stages breaks open to release uni- and multinucleate cells. The latter develop into sporogonial plasmodia covered by a wall derived from the layer of ledges covering the meronts, now represented by a labyrinth of dense-core partitions. Later, the wall of the SPV becomes flattened to form a dense amorphous layer, the outer surface of which is covered by a layer of flattened membranous cisternae. Sporogony is polysporoblastic and proceeds by repeated segmentation of the sporogonial plasmodium, resulting in a variable and large number of spores within SPVs.
- Spores with a huge posterior vacuole are as a rule dimorphic, macro- and microspores. Both types of spores differ in size but are similar except for the relative size of the posterior vacuole and number of turns of the polar tube. The minute spores, markedly smaller than microspores, are not always present.

- They are typically parasites of fish oocytes.

Acknowledgement. This work has been supported by grant No. 524/98/0589 awarded by the Grant Agency of the Czech Republic.

\section{LITERATURE CITED}

Canning EU, Hazard EI (1982) Genus Pleistophora Gurley, 1893: an assemblage of at least three genera. J Protozool 29:39-49

Canning EU, Nicholas JP (1980) Genus Pleistophora (Phylum Microspora): redescription of the type species, Pleistophora typicalis Gurley, 1893 and ultrastructural characterization of the genus. J Fish Dis 3:317-338

Canning EU, Hazard EI, Nicholas JP (1979) Light and electron-microscopy of Pleistophora sp. from skeletal muscle of Blennius pholis. Protistologica 15:317-332

Cheney SA, Lafranchi-Tristem NJ, Canning EU (2000) Phylogenetic relationships of Pleistophora-like microsporidia based on small subunit ribosomal DNA sequences and implications for the source of Trachipleistophora hominis infections. J Eukaryot Microbiol 47:280-287

Hollister WS, Canning EU, Weidner E, Field AS, Kench J, Marriott DJ (1996) Development and ultrastructure of Trachipleistophora hominis n.g., n.sp. after in vitro isolation from an AIDS patient and inoculation into athymic mice. Parasitology 112:143-154

Lom J, Corliss JO (1967) Ultrastructural observations on the development of the microsporidian protozoon Plistophora hyphessobryconis Schäperclaus. J Protozool 14:141-152

Maurand J, Loubes C, Gasc C, Pelletier J, Barral J (1988) Pleistophora mirandellae Vaney \& Conte, 1901, a microsporidian parasite in cyprinid fish of rivers in Hérault: taxonomy and histopathology. J Fish Dis 11:251-258

Nilsen F (2000) Small subunit ribosomal DNA phylogeny of microsporidia with particular reference to genera that infect fish. J Parasitol 86:128-133

Nilsen F, Endresen C, Hordvik I (1998) Molecular phylogeny of microsporidians with particular reference to species that infect the muscle of fish. J Eukaryot Microbiol 45: $535-543$

Otte E (1964) Mikrosporidien bei Donaufischen. Wien Tierärzt Monatschr 51:316-319

Pekkarinen M (1995) Pleistophora mirandellae Vaney \& Conte, 1901 (Protozoa: Microspora) infection in the ovary of the roach, Rutilus rutilus (L.) from Finnish coastal waters. Memo Soc Fauna Flora Fenn 71:19-32

Pekkarinen M (1996a) Infections of Pleistophora mirandellae Vaney \& Conte, 1901 (Protozoa: Microspora) in fish gonads in a lake in central Finland. Memo Soc Fauna Flora Fenn $72: 1-5$

Pekkarinen M (1996b) Ultrastructure of the wall of the sporophorous vesicle during sporogony of Pleistophora mirandellae (Protozoa: Microspora). Parasitol Res 82:740-742

Pekkarinen M, Lom J (1999) Ultrastructure of a microsporidian parasite from oocytes of ruff (Gymnocephalus cernuus) from Finland. 5th International Symposium on Fish Para- 
sites, Institute of Parasitology, ASCR, 9-13 August, 1999, České Budějovice, Czech Republic, p 110

Summerfelt RC, Warner MC (1970) Incidence and intensity of infection of Plistophora ovariae, a microsporidian parasite of the golden shiner, Notemigonus crysoleucas. In: Sniezsko SF (ed) A symposium on diseases of fishes and shellfishes. American Fisheries Society, Washington, Spec Publ, Vol 5, p 142-160

Editorial responsibility: Wolfgang Körting,

Hannover, Germany
Swofford DL (2000) PAUP*. Phylogenetic analysis using parsimony ( ${ }^{*}$ and other methods). Version 4. Sinauer Associates, Sunderland

Vaney C, Conte A (1901) Sur une nouvelle Microsporidie, Pleistophora mirandellae, parasite de l'ovaire d'Alburnus mirandella Blanch. C R Acad Sci Paris 133:644-646

Weiser J (1949) Studies on some parasites of fishes. Parasitology 39:164-166

Submitted: March 6, 2001; Accepted: June 25, 2001

Proofs received from author(s): February 8, 2002 